Grzegorz PRZYBYŁA ${ }^{1}$

Stefan POSTRZEDNIK ${ }^{2}$

Zbigniew ŻMUDKA ${ }^{3}$

\title{
THE HEAT TRANSFER COEFFICIENT CALCULATIONS OF INTERNAL COMBUSTION ENGINE FUELLED WITH NATURAL GAS
}

\begin{abstract}
In this paper the calculations of heat transfer coefficient in the combustion chamber of the internal combustion engine fuelled with natural gas is presented. The mean value of heat transfer coefficient has been calculated using Woschni and Nusselt equation and compared with results obtained using algorithm based on experimental data. The proposed algorithm can be helpful to determine the average values of heat transfer coefficient from working medium to the combustion chamber walls (crown of a cylinder head, cylinder walls and piston head) during combustion process. The calculation method includes modified one zone heat release model in combustion chamber of SI engine. Proposed method is based on the energy balance equation closed by the coefficient which expresses the heat losses to the walls of the combustion chamber.
\end{abstract}

Keywords: heat transfer coefficient, combustion engines, in-cylinder pressure

\section{Introduction}

There are two main methods which describe the phenomena occurring in the cylinder of combustion engine. The first method applies the macroscale models. In this approach a few zones are investigated (eg. flame, unburned mixture, exhaust) with different degrees of fidelity of real phenomena. These type of mathematical models give a good quantitative results and their main advantage is short computation time. The weak point is the lack of information on the instantaneous values of the analyzed parameters in different places of engine combustion chamber. However, in many cases, the phenomenological macroscale models are sufficient in the engine parameters calculations. The second method based on multidimensional models which enable to determine instantaneous

\footnotetext{
${ }^{1}$ Autor do korespondencji/corresponding author: Grzegorz Przybyła, Silesian University of Technology, 22 Konarskiego Street, 44-100 Gliwice, Poland, tel.: (32) 2372983, e-mail: gprzybyla @ polsl.pl

${ }^{2}$ Stefan Postrzednik, Silesian University of Technology, e-mail: spostrzednik@ polsl.pl

${ }^{3}$ Zbigniew Żmudka, Silesian University of Technology, e-mail: zzmudka@polsl.pl
} 
value of internal parameters at chosen places of combustion chamber. In this paper the single-zone heat release model was used in the computations. It was assumed that at any time of the combustion process, the working medium contained in the cylinder is homogeneous. Moreover, the thermodynamic state of working medium describes the averaged values of thermodynamic parameters specified for instantaneous value of cylinder volume. The initial condition of working medium is it's the state after compression (the homogenous air-fuel mixture). The scheme of combustion chamber energy balance is presented in fig. 1 . The following assumptions have been made: the working medium is considered as a ideal gas with a change of composition during combustion process, the specific heat is a function of average temperature in cylinder, the change of working medium composition is taken into account by instantaneous value of fuel mass fraction burned (MFB) the heat losses into the combustion chamber walls are closing the energy balance equation.

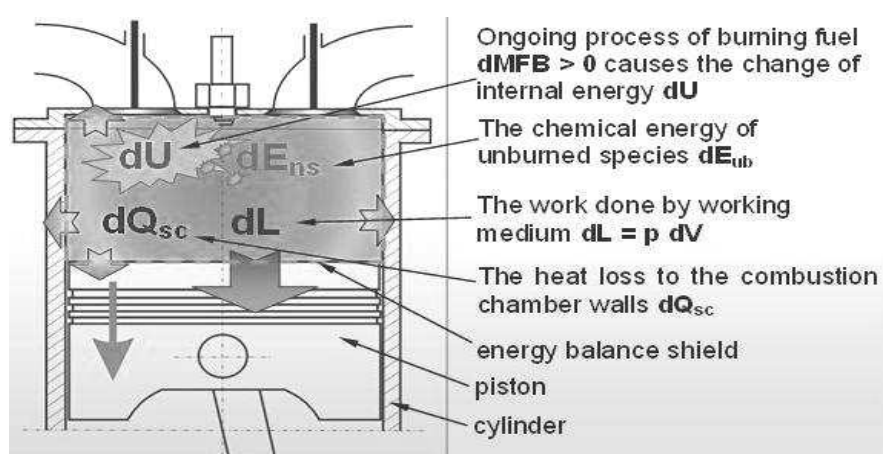

Fig. 1. Energy balance of engine combustion chamber

The chemical energy of the fuel is a significant part of the energy balance equation. The energy is released gradually according to combustion process rate, what is expressed by MFB function. Besides, the balance equation includes the change of total internal energy and internal work. The heat losses are close to the balance. Finally, the energy balance equation can be described using the first law of thermodynamic, as follow:

$$
\mathrm{d} U+\mathrm{d} L+\mathrm{d} Q_{s c}+\mathrm{d} E_{n s}=0
$$

where: $\mathrm{d} U$ - internal energy change, $\mathrm{d} L$ - elementary internal work done by working medium, $\mathrm{d} Q_{s c}$ - elementary heat losses transferred to combustion chamber walls, $\mathrm{d} E_{u b}$ - chemical energy of unburned fuel.

Taking into account the equation of state for ideal gas in the eq. (1) and next describing it in differential form without heat loss, the heat release rate equation (net value) is described as follows: 


$$
\frac{\mathrm{d} E}{\mathrm{~d} \alpha}=\frac{1}{\left[1-\delta_{u b} \frac{L H V_{u b}}{L H V_{f}}\right]}\left[\frac{1}{\kappa\left(T, M F B_{v}\right)-1}\left(\kappa\left(T, M F B_{v}\right) p(\alpha) \frac{\mathrm{d} V}{\mathrm{~d} \alpha}+V(\alpha) \frac{\mathrm{d} p}{\mathrm{~d} \alpha}\right)\right]
$$

where: $\kappa\left(T, M F B_{v}\right)$ - the function of the specific heat ratio, $V(\alpha)$ - the engine volume as a function of the crank angle, $p(\alpha)$ - the in-cylinder pressure measured as a function of the crank angle, $\delta_{u b}$ - the mass fraction of unburned fuel, $L H V_{u b}$ - lower heating value of unburned species at the working medium, $L H V_{f}$ - lower heating of the fuel.

After integration the eq. (2) at the range of combustion period from $\alpha_{p}$ (start of combustion) to $\alpha^{*}$ (current value of crank angle during combustion), the net amount of energy realised in the cylinder can be expressed by:

$$
\begin{aligned}
& E_{d}\left(\alpha^{*}\right)= \\
& =\frac{1}{\left(1-\delta_{u b} \frac{L H V_{u b}}{L H V_{f}}\right)} \int_{\alpha_{p}}^{\alpha^{*}}\left[\frac{1}{\left[\kappa\left(T, M F B_{v}\right)-1\right]}\left(\kappa\left(T, M F B_{v}\right) p(\alpha) \frac{\mathrm{d} V}{\mathrm{~d} \alpha}+V(\alpha) \frac{\mathrm{d} p}{\mathrm{~d} \alpha}\right)\right] \mathrm{d} \alpha
\end{aligned}
$$

where: $\alpha^{*}$ - current value of crank angle during combustion process, $\alpha_{p}-$ value of crank angle at start of combustion process.

The upper limit of integration reaches the values from the range of $\left[\alpha_{p}-\alpha_{k}\right]$, where the $\alpha_{k}$ is the value of crank angle at the end of combustion process. The total amount of net heat released in the cylinder will reach when $\alpha^{*} \rightarrow \alpha_{k}$. The actual heat input to the cylinder during a single working cycle is related to the amount of chemical energy contained at the fuel dose. Therefore, the amount of chemical energy supplied to the cylinder can be noted as:

$$
E_{x, 0}=m_{p, 0} L H V_{f}
$$

where $m_{p, 0}-$ fuel dose supplied on single engine cycle.

The value of heat losses can be determined by subtracting the amount of net heat released in the cylinder (eq. (3)) from the actual heat supplied during the working cycle (eq. (4)). Then the final equation of the heat losses during combustion process is as below [4]: 


$$
\begin{aligned}
& Q_{s c}=m_{p, 0} L H V_{f}+ \\
& -\frac{1}{\left(1-\delta_{n s} \frac{L H V_{u b}}{L H V_{f}}\right)} \int_{\alpha_{p}}^{\alpha_{k}}\left[\frac{1}{\left[\kappa\left(T, M F B_{v}\right)-1\right]}\left(\kappa\left(T, M F B_{v}\right) p(\alpha) \frac{\mathrm{d} V}{\mathrm{~d} \alpha}+V(\alpha) \frac{\mathrm{d} p}{\mathrm{~d} \alpha}\right)\right] \mathrm{d} \alpha
\end{aligned}
$$

The specific heat ratio employed in this model was calculated as a function of the in-cylinder temperature and the charge composition. Determination of the total heat loss during combustion process, according to the eq. (5) allows designation of the heat transfer coefficient of the working medium to the wall of the engine combustion chamber.

\section{Heat transfer coefficient calculations}

There are many papers [e.g. 1, 2, 3], which describe the methodology how to determine the heat transfer coefficient in internal combustion engine. However, usually each formula presented in the literature gives different values, even is used for the same engine and in the same engine working condition. These empirical equations based on observations using the turbulent heat transfer equations for tubes. One of the most popular formula to determine the heat transfer coefficient is developed by Woschni. For combustion period and expansion process the equation can be written as:

$$
\alpha_{s c, W}=820 D^{-0.2} p(\alpha)^{0.8}\left[2.28 \bar{w}_{p}+3.24 \cdot 10^{-3} \frac{V_{s} T_{2}}{p_{2} V_{2}}\left(p(\alpha)-p_{0}\right)\right]^{0.8} T(\alpha)^{-0.53}
$$

where: $\bar{w}_{p}$ - mean piston speed, function of the specific heat ratio, $p(\alpha)-$ instantaneous cylinder pressure, $T(\alpha)$ - instantaneous cylinder temperature, $V(\alpha)$ - swept volume, $p_{2}, T_{2}, V_{2}$ - parameters evaluated at start of combustion process, $p_{0}$ - motoring pressure.

The second equation is given by Nusselt [3]:

$$
\alpha_{s c, N}=5.41 \cdot 10^{-4} \sqrt[3]{p(\alpha)^{3}} T(\alpha)\left(1+1.24 \bar{w}_{p}\right)
$$

The heat transfer from the combustion products occurs by convection and radiation. The value of the heat transfer coefficient obtained by eq. (6) and (7) includes convection only. In the spark ignition engine radiation may account for up to 20 per cent of the heat transfer. Adopting such an assumption it will be 
possible to check what is the difference in results obtained by Woschni and Nusselt equation and when using algorithm based on net heat release in cylinder.

In accordance with the principles of heat transfer, the heat flux, transferred from the combustion products to the walls of the working engine space can be described:

$$
\dot{Q}_{s c}=A(\alpha) \alpha_{s c}\left[T(\alpha)-T_{s c}\right]
$$

where: $A(\alpha)$ - instantaneous heat exchange surface (crown of a cylinder head, cylinder walls and piston head), $\alpha_{s c}$ - total heat transfer coefficient (includes convection and radiation), $T(\alpha)$ - instantaneous cylinder temperature, $T_{s c}-$ average temperature of the heat exchange surface.

There is the following correlation between the heat flux $\dot{Q}_{s c}$ and the heat loss rate $\mathrm{d} Q_{s c} / \mathrm{d} \alpha$ :

$$
\dot{Q}_{s c}=\frac{\mathrm{d} Q_{s c}}{\mathrm{~d} \alpha} \frac{\mathrm{d} \alpha}{\mathrm{d} t}, \quad \dot{Q}_{s c}=\omega \frac{\mathrm{d} Q_{s c}}{\mathrm{~d} \alpha}
$$

where $\omega$ - engine angular velocity.

Using the eq. (8) in formula (9), the heat loss rate can be described:

$$
\frac{\mathrm{d} Q_{s c}}{\mathrm{~d} \alpha}=\frac{1}{\omega} A(\alpha) \alpha_{s c}\left[T(\alpha)-T_{s c}\right]
$$

and after integration the eq. (10) in range of combustion period it is possible to determine the heat transfer coefficient based on heat losses:

$$
Q_{s c}=\frac{1}{\omega} \int_{\alpha_{p}}^{\alpha_{k}} \alpha_{s c} A(\alpha)\left[T(\alpha)-T_{s c}\right] \mathrm{d} \alpha
$$

Finally using eq. (10) and eq. (11), the mean value of heat transfer coefficient during combustion process is possible to calculate using following equation:

$$
\bar{\alpha}_{s c}=\frac{\omega Q_{s c}}{\int_{\alpha_{p}}^{\alpha_{k}} A(\alpha)\left[T(\alpha)-T_{s c}\right] \mathrm{d} \alpha}
$$

where $\bar{\alpha}_{s c}-$ mean value of heat transfer coefficient taking into account convection and radiation. 


\section{The engine test rig and experimental results}

The picture of the engine test stand and measuring equipment is presented in fig. 2. The main components of the experimental set up include:

- three cylinders SI engine with a capacity of $796 \mathrm{~cm}^{3}$ and compression ratio equal to 9.3. The engine is without turbocharging and was originally powered by petrol. For the purpose of experiment and possibility of gaseous fuel application, the control and power supply systems of the engine have been modified,

- electric motor with the power take-off system, capable of operating in two modes, the motor and generator. The main purpose of this system is to start the engine and then to apply load on the selected point of the operating cycle,

- measuring devices for flow rate, temperature and pressure evaluation including: rotameter, manometers and thermocouples.

During experiment the engine was fuelled with natural gas coming from the gas grid. The air-fuel mixture has been changed in range from stoichiometric to lean mixture $(\lambda=1.0-1.5)$. The crank angle (ignition advance angle) was regulated in the range between $5 \mathrm{deg}$ and $40 \mathrm{deg}$ of the crankshaft rotation before the piston reaches top dead centre (TDC).

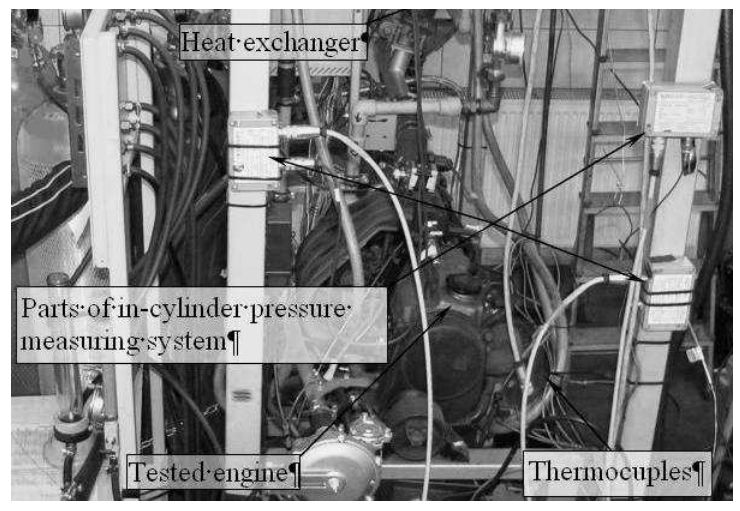

Fig. 2. The test stand with SI engine

Comparison of the results obtained by experimental algorithm (eq. (12)) presented in this paper with the results calculated by Woschni and Nusselt function (eq. (6), (7)), for 4 values of air excess ratio $(\lambda=1, \lambda=1.1, \lambda=1.3$ and $\lambda=1.5)$ and different ignition timing is shown in figs. 3-6. 


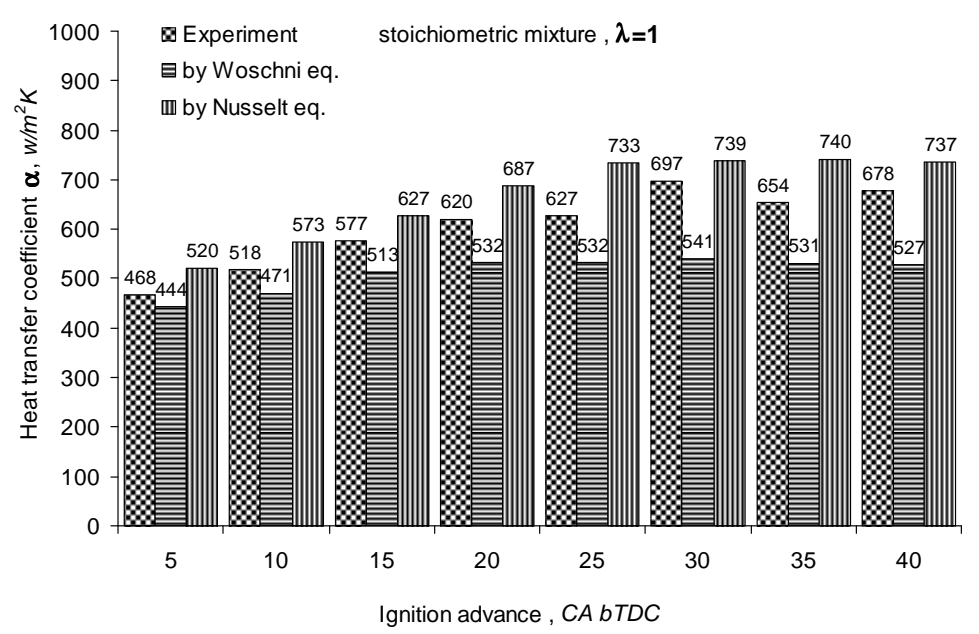

Fig. 3. Comparison of the results for constant air excess ratio $\lambda=1$ and changing ignition timing

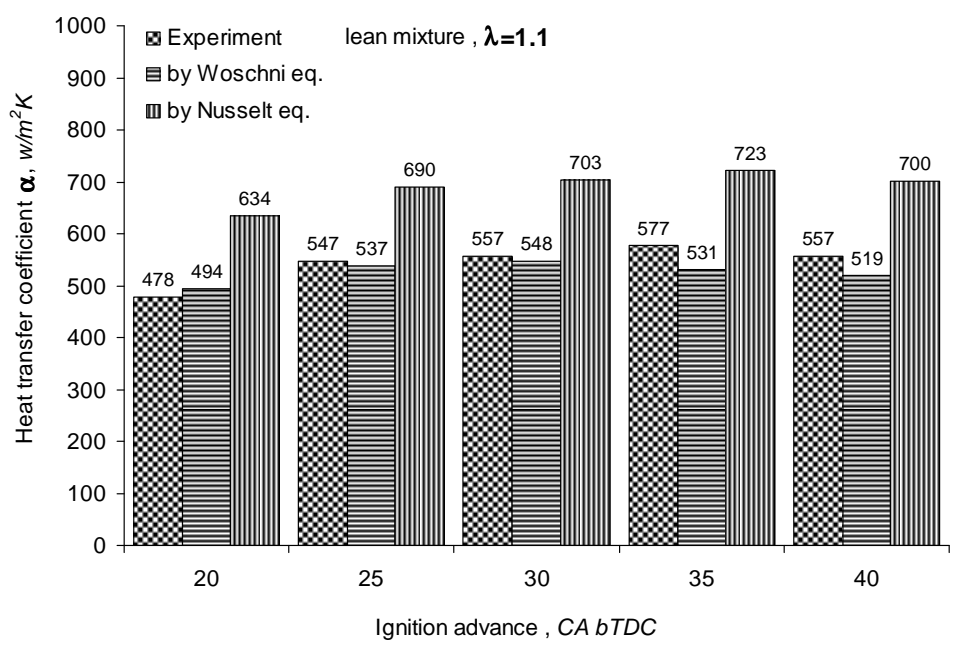

Fig. 4. Comparison of the results for constant air excess ratio $\lambda=1.1$ and changing ignition timing

During experiments the engine run with full load (fully open throttle). Presented results refer to combustion period only. Results obtained for stoichiometric mixture show quite good qualitative agreement comparing to the experimental results with Nusselt equation. The values obtained for Nusselt equation are 


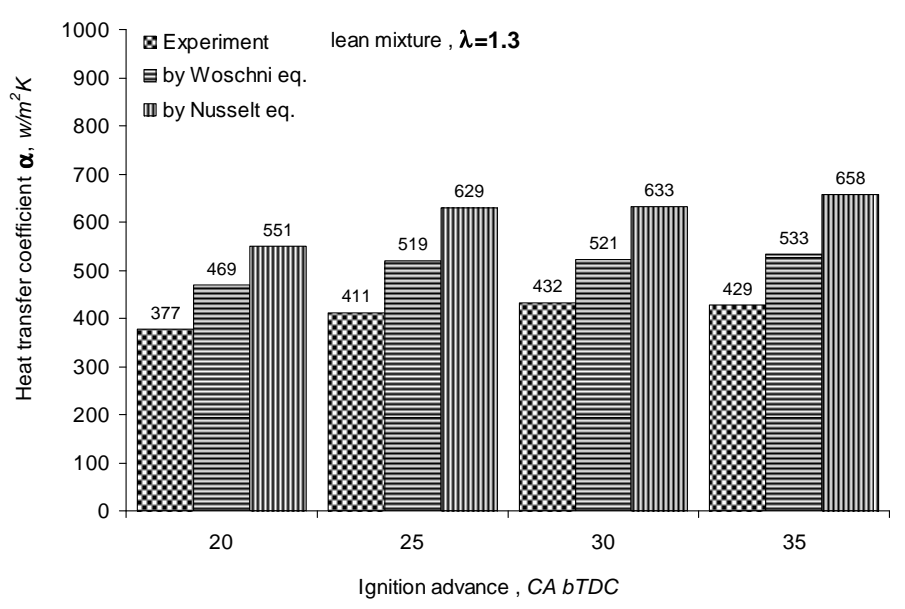

Fig. 5. Comparison of the results for constant air excess ratio $\lambda=1.3$ and changing ignition timing

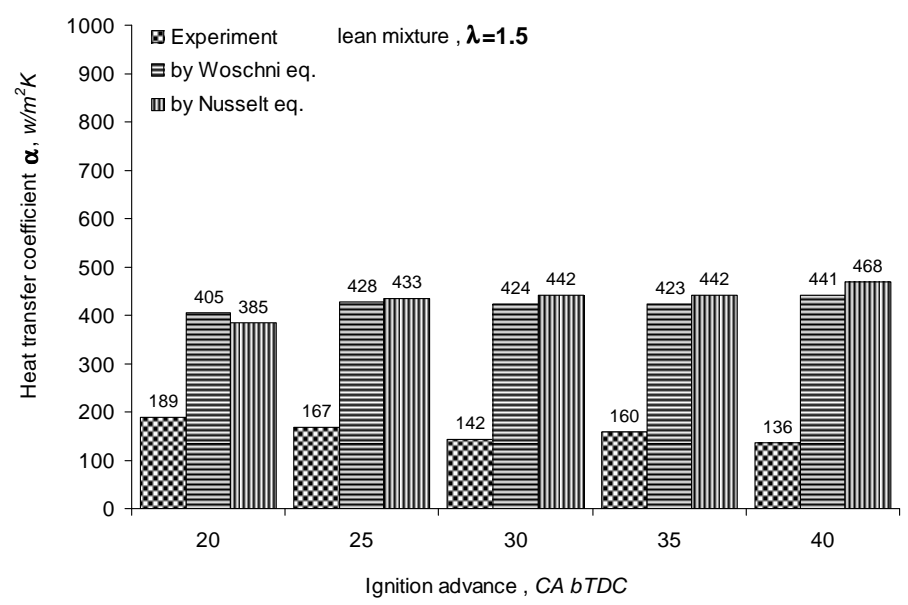

Fig. 6. Comparison of the results for constant air excess ratio $\lambda=1.5$ and changing ignition timing

significantly higher than for experiment. Much better quantitative agreement is achieved for Woschni formula (if the radiation will be taken into account). The leaner mixture the worse agreement between experimental results and tested formulas is observed. 


\section{Conclusions}

The results obtained using Woschni equation and proposed algorithm based on cylinder pressure function are qualitatively comparable (if the radiation is taken into account) but mainly for stoichiometric mixture and optimal ignition timing (for MBT - maximum brake torque). The highest differences in values obtained for used equations (Woschni and Nusselt) exceed 300\% comparing to experimental results (using heat release algorithm proposed in this paper) and these differences are observed for lean mixtures and higher ignition timing. The heat transfer from the combustion products occurs by convection and radiation, when the value of the heat transfer coefficient obtained by Woschni and Nusselt equation includes convection only. It is one of the reason which leads to the high difference (for much operating points of ICE) in obtained results. Presented in this paper algorithm involves all major physicochemical phenomena occurring in the system during combustion process. These phenomena have a significant impact on obtained results. Finally, regarding to it, the presented algorithm should bring more realistic values than the universal equations.

\section{Acknowledgement}

This work is supported by the Silesian University of Technology from the statutory research source of Institute of Thermal Technology.

\section{References}

[1] Buckmaster J., Clavin P., Linan A., Matalon M., Peters N., Sivashinsky G., Williams F.A.: Combustion theory and modeling, Proc. Combustion Institute, vol. 30, Pittsburgh 2005, pp. 1-19.

[2] Corcione F.E., et al., Temporal and spatial evolution of radical species in the experimental and numerical characterization of diesel auto-ignition, COMODIA 2001, Nagoya 2001, pp. 355-363.

[3] Nusselt W.: Der Warmeubergang in der Verbrennugs-kraft-maschine, V.D.I. Forschungsheft, No. 264, 1923.

[4] Przybyła G., Postrzednik S.: Analiza warunków wymiany ciepła w cylindrze silnika spalinowego, [w:] Termodynamika w nauce i gospodarce, t. II, pod red. Z. Gnutka i W. Gajewskiego, Oficyna Wydawnicza Politechniki Wrocławskiej, Wrocław 2008.

\section{OBLICZENIA WSPÓŁCZYNNIKA PRZENIKANIA CIEPŁA SILNIKA WEWNĘTRZNEGO SPALANIA ZASILANEGO GAZEM ZIEMNYM}

\section{Streszczenie}

W pracy przedstawiono obliczenia współczynnika przenikania ciepła w komorze spalania silnika wewnętrznego spalania zasilanego gazem ziemnym. Średnią wartość współczynnika przenikania ciepła obliczono za pomocą równania Woschni oraz Nusselta i porównano z wynikami uzyskanymi za pomocą algorytmu opartego na danych eksperymentalnych. Zaproponowany 
algorytm może być pomocny do określenia średnich wartości współczynnika przenikania ciepła z czynnika roboczego do ścian komory spalania (głowicy cylindra, ściany cylindrów i głowicy tłoka) podczas procesu spalania. Metoda obliczeniowa obejmuje zmodyfikowany model wydzielania ciepła w komorze spalania silnika ZI. Proponowany sposób opiera się na równaniu bilansu energetycznego zamkniętym przez współczynnik, który wyraża straty ciepła do ścianek komory spalania.

Słowa kluczowe: współczynnik przenikania ciepła, silniki spalinowe, ciśnienie w cylindrze

DOI: $10.7862 / \mathrm{rm} .2015 .8$

Otrzymano/received: $15.09 .2014 \mathrm{r}$.

Zaakceptowano/accepted:30.10.2014 r. 